DOI: https://doi.org/10.47405/mjssh.v6i12.1226

\begin{tabular}{|c|c|}
\hline 4.581 & Malaysian Journal of Social Sciences and Humanities (MJSSH) \\
\hline $\begin{array}{l}\text { Malaysian Journal of } \\
\text { socal s ciences and }\end{array}$ & Volume 6, Issue 12, December 2021 \\
\hline (MJ-SSH) & e-ISSN : 2504-8562 \\
\hline & $\begin{array}{l}\text { Journal home page: } \\
\text { www.msocialsciences.com }\end{array}$ \\
\hline
\end{tabular}

\title{
Negative Health Effects of Excessive Alcohol Consumption: A Systematic Review
}

\author{
Rubiah Anak Ajan' ${ }^{1}$, Vivien Yew Wong Chin ${ }^{1}$, Abd Hair Awang ${ }^{1}$ \\ 1 Faculty of Social Sciences and Humanities, The National University of Malaysia (UKM), Malaysia
}

Correspondence: Rubiah Anak Ajan (email: p93263@siswa.ukm.edu.my)

\begin{abstract}
Drinking alcohol is one of the risk that faces the society, and the public health authorizes as well as the economics of countries. Several studies were conducted to understand the status of alcohol consumption. However, few studies reviewed the literature to identify the status quo of alcohol. This study aims to review the literature related to alcohol consumption. Keywords that are related to the topic were used to search for articles in reliable databases. The articles were filtered based on time, scope, language, and index. A timeframe of four years was used to have an update view of the consumption of alcohol. Only English articles related to alcohol consumption were used. The results of this systematic literature review indicate that most of the previous studies are quantitative. In addition, the result also showed that there is limited studies in developing countries. Social, economic and family related issues are consequence of excessive consumption of alcohol. There is a need for more studies in non-western context to understand the status and possible remedy for alcohol consumption.
\end{abstract}

Keywords: alcohol, cancer, alcoholism, culture, liver cirrhosis

\section{Introduction}

An estimated 2 billion people are involved in alcohol and alcohol consumption activities, causing 76.3 million health problems. This risk of alcohol consumption is not confined to the quantity and frequency of alcohol consumption, but is also associated with an irregular pattern of consumption that may cause health harm (Mehrabi et al., 2019; Mutalip et al., 2014; WHO, 2011; Fogarty, 2009). Global statistics show an increase in alcohol use (Adzrago, Doku \& Adu Gyamfi 2018; Martin \& Martin, 2019; Mehrabi et al., 2019; MOH Malaysia, 2013; Mutalip et al., 2014). Alcohol use disorders (AUD) show a prevalence of $10 \%$ among US and European populations, and is one of the most common causes of liver cirrhosis in Europe (Magistri et al., 2019). Alcohol consumption is high among Americans and statistically increases the number of alcohol-related deaths in the country (Fernandez et al., 2019).

Alcohol is an addictive substance that is very commonly used around the world. Alcohol or ethanol $(\mathrm{C} 2 \mathrm{H} 5 \mathrm{OH})$ in alcoholic beverages is a drug from a depressant (oppressive) drug group that can slow the body's nervous and physical activity. Alcohol is also seen as a trigger for deviant behavior if taken too much. According to Hisyam (2004), alcoholic beverages when taken irrespective of whether they are made from wine, apples, wheat or sugar cane are classified as alcohol because of their weakening of the nervous system. Therefore, worse harm such as unconsciousness, prolonged sleep, coma and death are the result of consuming alcohol in excessive quantities (Noor et al., 2018). Alcohol is also 
identified as a group 1 carcinogen produced by the International Agency for Research on Cancer (IARC). Carcinogen is a substance that can cause cancer in human tissues. Globally, approximately $5.5 \%$ of cancer cases and $5.8 \%$ of cancer-related deaths are caused by alcohol consumption. Chronic alcohol consumption is an important contributing factor to many types of cancer (Xie, Feng \& Mao, 2019). The purpose of this article is to review and analyze the literature to understand the status of alcohol consumption.

\section{Methodology}

This study is a systematic study aimed at identifying issues related to harmful alcohol use and gaps in previous studies and providing direction for future research. This study is to identify articles related to alcohol use and the effects of excessive alcohol consumption. Keywords used in studies such as liver disease, cirrhosis of the liver, cancer, alcoholism, alcohol overload, alcohol use. This combination of keywords is used to find articles in three major databases related to alcohol use. Article search is by using three databases such as Science Direct, Web of Science and PubMed. Article selection criteria are limited to include only articles written in English and published in peer-reviewed and trusted journals. The methods of articles selection were using PRISMA 2020 statement comprised of 27-item checklist.

Figure 1: Selection and Screening process

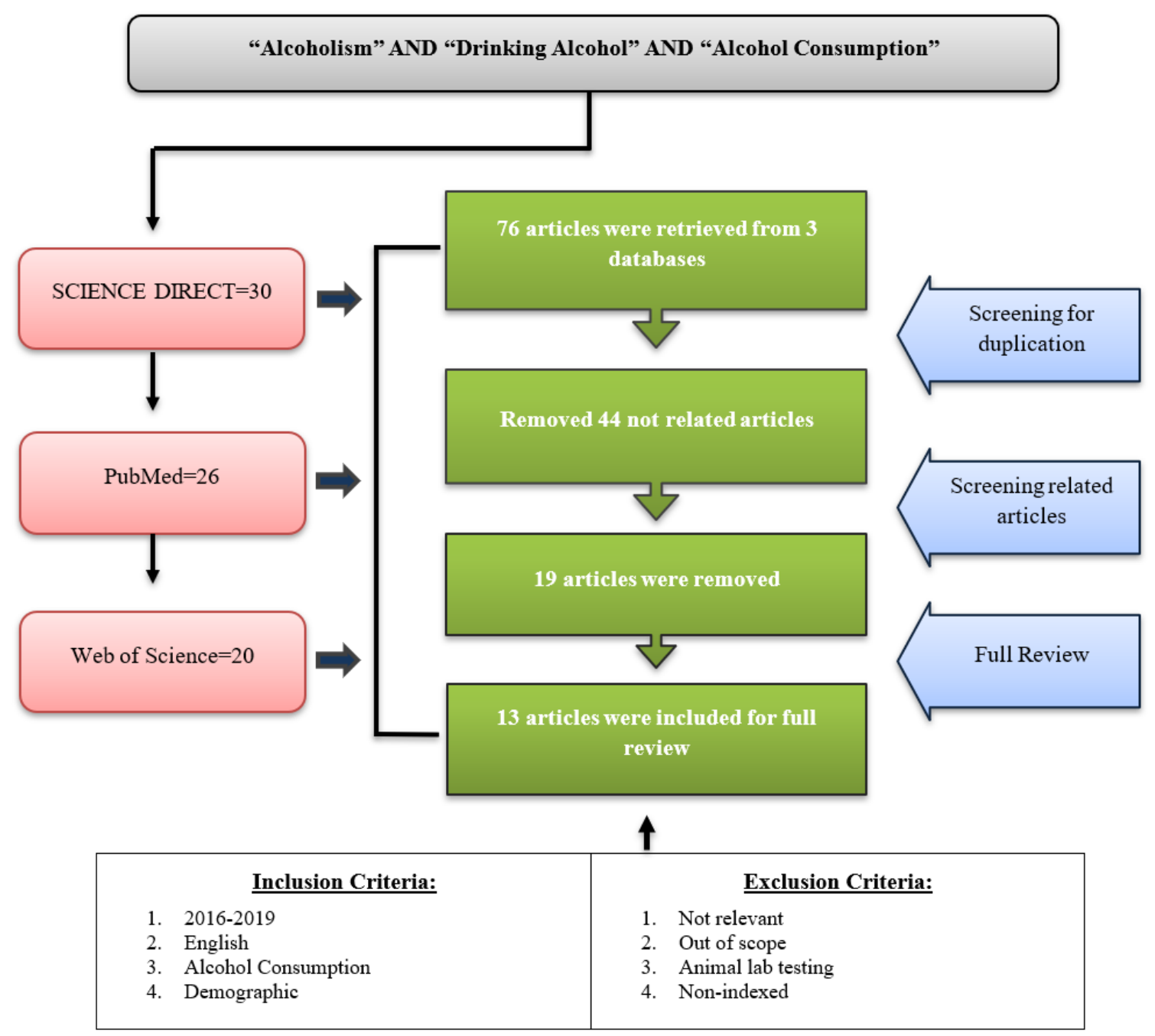

Source: Page et al. (2021) 
The articles in this study were published between 2016 and 2019. A total of 76 articles were extracted from three databases. Three stages of filtering were performed for the articles selected most relevant to this study. The first filter involves duplicate checks by including 76 articles as a selection list. The second stage filter involves the reading of related and abstract titles in which 44 unrelated articles are published. The third filter involved the full reading of the article, checking the scope of the article and finally releasing 19 unrelated articles. The final articles included in this study were 13 articles.

\section{Summary of Reviewed Studies}

A review of 13 articles was conducted to understand the outcome of alcohol consumption. Lackner and Tiniakos (2019) examined the effect of alcohol consumption on liver disease and found that liver cirrhosis is significant in women and age factors are increasing. Also depends on the quantity and duration of alcohol intake. In addition, a study by Fernandez et al. (2019) found that patients with liver cirrhosis underwent AUD treatment within 1 year after diagnosis, however, acceptance of AUD treatment was higher among men than women. Studies also found that alcohol consumption is directly related to liver diseases. For instance, Lucey (2019) found that Alcohol -related liver cirrhosis accounts for 50\% of the overall burden of liver cirrhosis in the United States. Magistri et al. (2019) found that alcohol consumption is the most common cause of liver cirrhosis in European countries.

Gupta, Long and Bai (2019) found that cirrhosis of the liver occurs when inflammation and liver undergo a phase of damage in which the liver becomes fibrotic and causes tissue damage. Similarly, Yan-Di Xie et al. (2019) found 60\% of the respondents were alcohol drinkers including harmful and hazardous drinkers. Increased alcohol consumption leads to increase the risk of getting liver cirrhosis. Tommaso Stroffolini et al. (2018) examined the demographic and alcohol intake and their effect on liver chronic disease. The findings showed that Risky alcohol consumption play crucial role of more than one-fifth of chronic liver disease (CLD). 2717 were risky drinkers out of 12,256. Gro Askgaard et al. (2018) examined also the effect of alcohol intake on alcohol liver cirrhosis. The findings showed that Consistent management of alcohol problems in hospital patients has been suggested as a prevention strategy for alcoholic liver cirrhosis. The increase in alcoholic liver cirrhosis lead to increase in number of alcohol hospital contacts. Mellinger et al. (2018) examined the knowledge and perception of alcohol related cirrhosis. The findings showed that the strongest barrier was not willing to be in included in the treatment and inaccurate perception of the side effect of the medication as well as having very little knowledge. Table 1 shows a summary of the reviewed studies. The table shows the number of articles, author, year, country, description of the study, independent variable (IV), dependent variable (DV), analysis unit, research design, data analysis, and findings.

The table 1 shows the synthesis matrix from previous studies divided into several sections such as author name, country of publication, year of publication, description of publication title, variables, unit of analysis, study design, data analysis and research results. The matrix synthesis table above shows previous studies that were systematically extracted and aggregated to see the clustering of previous studies.

The findings of the previous study showed a significant relationship between alcohol use and cirrhosis of the liver among women and the increasing age factor. Alcohol quantity and duration of alcohol intake are important contributing factors to cirrhosis of the liver (Lackner \& Tiniakos, 2019). However, studies on prostate cancer and alcohol consumption have shown no relationship between individuals consuming alcohol over a long period of life (Demoury, Karakiewicz \& Parent, 2016). Studies conducted in India have found that cirrhosis of the liver is the leading cause of liver damage in Asia, with higher quantity and frequency of alcohol consumption being at increased risk for liver cirrhosis (Gupta, Long \& Bai 2019). There is a significant relationship between genders when undergoing AUD (Alcohol Use Disorder) treatment after being diagnosed with liver disease among US residents, which has shown that men undergo higher treatment than women (Fernandez et al., 2019). Liver cirrhosis is a contributor to $50 \%$ of the burden of liver disease in the United States (Lucey, 2019). 
Table 1: Summary of Reviewed Articles

\begin{tabular}{|c|c|c|c|c|c|c|}
\hline Authors-Year-Country & IV's & DV & Analysis Unit & $\begin{array}{c}\text { Research } \\
\text { Design }\end{array}$ & $\begin{array}{c}\text { Data } \\
\text { Analysis }\end{array}$ & Findings \\
\hline $\begin{array}{l}\text { (Lackner \& Tiniakos, } \\
\text { 2019) Austria }\end{array}$ & $\begin{array}{l}\text { Alcohol } \\
\text { consumption }\end{array}$ & Liver Disease & Tissue biopsy & Quantitative & SPSS & $\begin{array}{l}\text { Liver cirrhosis is significant in women and age factors are increasing. Also } \\
\text { depends on the quantity and duration of alcohol intake }\end{array}$ \\
\hline $\begin{array}{l}\text { (Demoury, Karakiewicz } \\
\& \text { Parent, 2016) Canada }\end{array}$ & $\begin{array}{l}\text { Alcohol } \\
\text { consumption }\end{array}$ & Prostate Cancer & $\begin{array}{l}3927 \\
\text { respondents }\end{array}$ & Quantitative & $\begin{array}{l}\text { Logistic } \\
\text { regression }\end{array}$ & $\begin{array}{l}\text { There was no significant positive association between alcohol intake among } \\
\text { individuals who consumed alcohol throughout their lives with prostate } \\
\text { cancer. }\end{array}$ \\
\hline $\begin{array}{l}\text { (Gupta, Long \& Bai, } \\
\text { 2019) India }\end{array}$ & $\begin{array}{l}\text { Alcohol } \\
\text { consumption }\end{array}$ & Liver cirrhosis & Secondary data & Review & Review study & Chronic liver cirrhosis is caused by an increase in alcohol consumption. \\
\hline $\begin{array}{l}\text { (Fernandez et al., 2019) } \\
\text { USA }\end{array}$ & $\begin{array}{l}\text { Treatment of } \\
\text { alcohol } \\
\text { consumption }\end{array}$ & Liver cirrhosis & $\begin{array}{l}66,053 \\
\text { respondents }\end{array}$ & Quantitative & SPSS & $\begin{array}{l}\text { Patients with liver cirrhosis underwent AUD treatment within } 1 \text { year after } \\
\text { diagnosis, however, acceptance of AUD treatment was higher among men } \\
\text { than women. }\end{array}$ \\
\hline (Lucey, 2019) USA & $\begin{array}{l}\text { Alcohol } \\
\text { consumption }\end{array}$ & Liver cirrhosis & $\begin{array}{l}29,4215 \\
\text { respondents }\end{array}$ & Quantitative & SPSS & $\begin{array}{l}\text { Alcohol -related liver cirrhosis accounts for } 50 \% \text { of the overall burden of } \\
\text { liver cirrhosis in the United States. }\end{array}$ \\
\hline $\begin{array}{l}\text { (Campollo, 2019) } \\
\text { Mexico }\end{array}$ & $\begin{array}{l}\text { Alcohol } \\
\text { consumption }\end{array}$ & Liver cirrhosis & Secondary data & Review & Review & $\begin{array}{l}\text { The high prevalence and mortality is due to liver cirrhosis, as well as } \\
\text { alcohol is a major factor to the cause of cirrhosis. }\end{array}$ \\
\hline $\begin{array}{l}\text { (Magistri et al., 2019) } \\
\text { Italy }\end{array}$ & $\begin{array}{l}\text { Alcohol } \\
\text { consumption }\end{array}$ & Liver Disease & $\begin{array}{l}102 \\
\text { respondents }\end{array}$ & Quantitative & SPSS & $\begin{array}{l}\text { Alcohol consumption is the most common cause of liver cirrhosis in } \\
\text { European countries. }\end{array}$ \\
\hline (Li et al., 2016) China & $\begin{array}{l}\text { Alcohol } \\
\text { consumption }\end{array}$ & $\begin{array}{l}\text { Cardiovascular } \\
\text { disease }\end{array}$ & $\begin{array}{l}11,269 \\
\text { respondents }\end{array}$ & Quantitative & $\begin{array}{l}\text { Regression } \\
\text { analysis }\end{array}$ & Excessive alcohol consumption is a risk factor for coronary heart disease. \\
\hline $\begin{array}{l}\text { (Song et al., 2016) } \\
\text { Korea }\end{array}$ & $\begin{array}{l}\text { Excessive } \\
\text { alcohol } \\
\text { consumption }\end{array}$ & $\begin{array}{l}\text { Alcohol related } \\
\text { liver disease }\end{array}$ & $\begin{array}{l}1,151 \\
\text { respondents }\end{array}$ & Quantitative & SPSS & $\begin{array}{l}\text { There is a significant interaction between excessive alcohol intake and liver } \\
\text { disease. }\end{array}$ \\
\hline $\begin{array}{l}\text { (Yan-Di Xie et al., } \\
\text { 2019) China }\end{array}$ & $\begin{array}{l}\text { Alcohol } \\
\text { consumption }\end{array}$ & Liver Disease & $\begin{array}{l}1489 \\
\text { respondents }\end{array}$ & Quantitative & SPSS & $\begin{array}{l}60 \% \text { of the respondents were alcohol drinkers including harmful and } \\
\text { hazardous drinkers. Increased alcohol consumption leads to increase the } \\
\text { risk of getting liver cirrhosis. }\end{array}$ \\
\hline $\begin{array}{l}\text { (Tommaso Stroffolini et } \\
\text { al., 2018) Italy }\end{array}$ & $\begin{array}{l}\text { Demographic } \\
\text { and alcohol } \\
\text { intake }\end{array}$ & $\begin{array}{l}\text { Alcohol chronic } \\
\text { liver diseases }\end{array}$ & 12,256 & Quantitative & SPSS & $\begin{array}{l}\text { Risky alcohol consumption play crucial role of more than one-fifth of } \\
\text { chronic liver disease (CLD). } 2717 \text { were risky drinkers out of } 12,256 \text {. }\end{array}$ \\
\hline $\begin{array}{l}\text { (Gro Askgaard et al., } \\
\text { 2018) Denmark }\end{array}$ & $\begin{array}{l}\text { Alcohol intake } \\
\text { Number of } \\
\text { hospital contacts }\end{array}$ & $\begin{array}{l}\text { Alcohol liver } \\
\text { cirrhosis }\end{array}$ & 36,044 & Quantitative & $\begin{array}{l}\text { SPSS } \\
\text { Stata } 14\end{array}$ & $\begin{array}{l}\text { Consistent management of alcohol problems in hospital patients has been } \\
\text { suggested as a prevention strategy for alcoholic liver cirrhosis. The increase } \\
\text { in alcoholic liver cirrhosis lead to increase in number of alcohol hospital } \\
\text { contacts. }\end{array}$ \\
\hline $\begin{array}{l}\text { (Jessica L. Mellinger et } \\
\text { al., 2018) USA }\end{array}$ & & $\begin{array}{l}\text { Alcohol related } \\
\text { cirrhosis }\end{array}$ & 123 & Qualitative & & $\begin{array}{l}\text { The strongest barrier was not willing to be in included in the treatment and } \\
\text { inaccurate perception of the side effect of the medication as well as having } \\
\text { very little knowledge }\end{array}$ \\
\hline
\end{tabular}


Previous studies have also shown that alcohol consumption is a contributing factor to cirrhosis and contributes to a high prevalence of death (Campollo, 2019). In line with the findings of a study conducted in Italy, high frequency of alcohol consumption is a leading cause of liver cirrhosis in European countries (Magistri et al., 2019). Alcohol use is associated with a number of liver-related diseases such as cirrhosis of the liver where liver cirrhosis occurs when the liver is in a phase of damage and inflammation which in turn causes the liver to stop functioning well (Gupta, Long and Bai 2019). Studies conducted in Korean men have found that there is a significant interaction between excessive alcohol consumption and liver damage (Song et al., 2016).

The findings from the previous study indicate that there is a lack of focus. Many previous studies have used quantitative approaches rather than mixed methods or qualitative methods. In addition, most of the previous studies are focused on developed countries and studies in developing countries are very limited. In Malaysia, in particular, there is a lack of research on alcohol consumption that focuses on studies of human behavior. Therefore, past studies are used as benchmarks to fill in the gap.

\section{Findings}

The findings are presented using descriptive and frequency analysis using SPSS and excel. The findings include the publication year, location of the study, study approach, and type of data analysis.

\section{Publication Year}

The year of publication is given in Figure 1. The figure below shows that the number of most published articles is in 2019 followed by articles in 2018 and 2016. In other years, the number of publications is low and this may be due to the different focus of the study being the priority and the least. Awareness of the importance of this topic to be given a specific focus on raising awareness of the dangers of alcohol use.

Figure 1: Year of Publication of articles

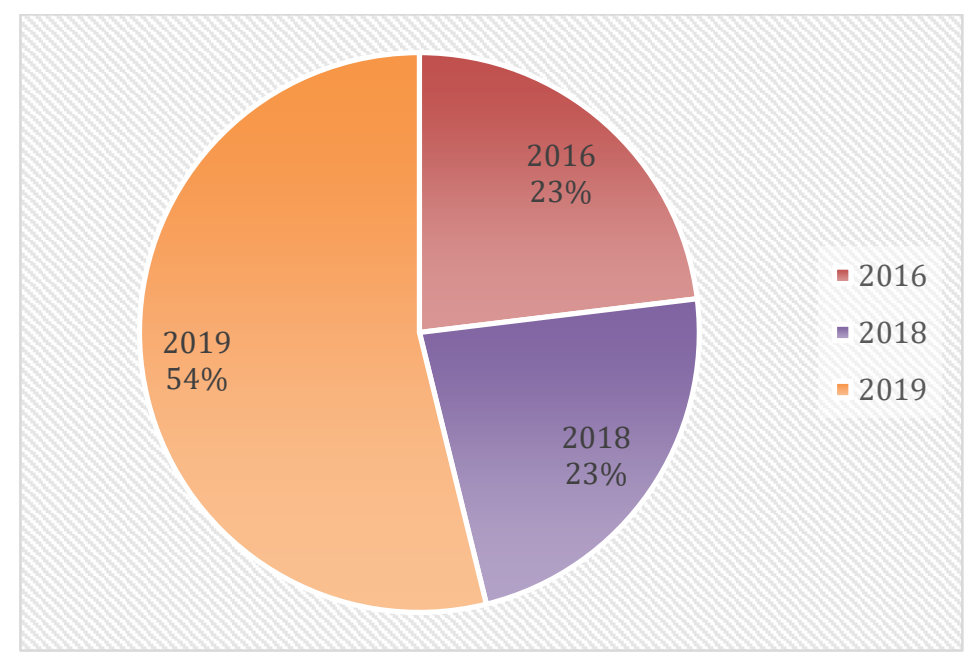

\section{Study approach}

Figure 2 shows the distribution of widely used methodological approaches in previous studies and is divided into 3 types. It can be seen that quantitative approaches are preferred over qualitative and review. 
Figure 2: Distribution of Study Approach

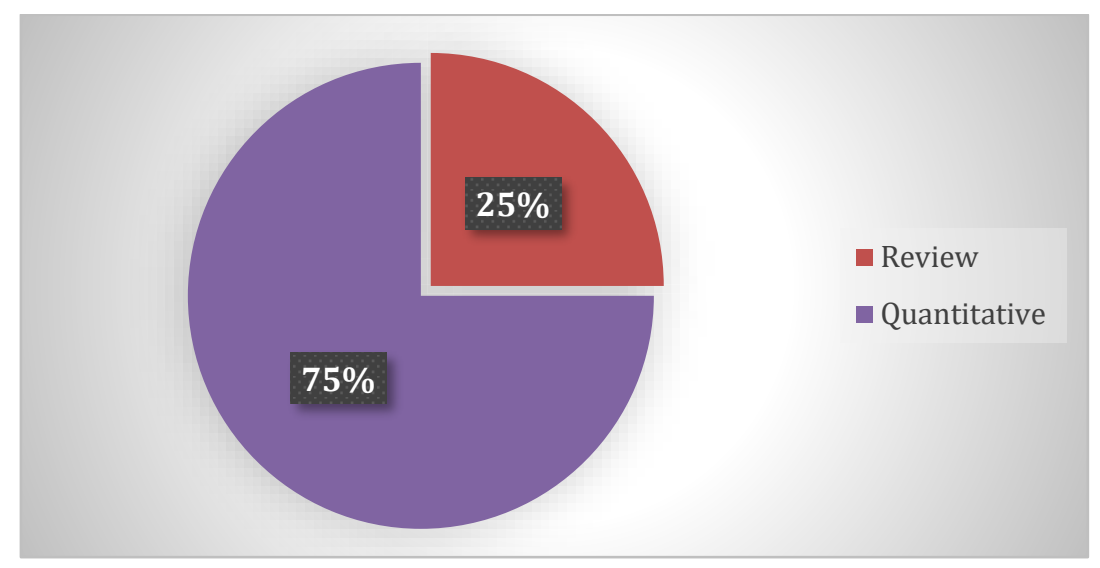

\section{Study Location}

The distribution of studies by location is given in figure 3. The United States shows the highest publication of articles followed by other countries such as Italy, China, Austria, Canada, Denmark, India, Mexico and Korea.

Figure 3: Study Location

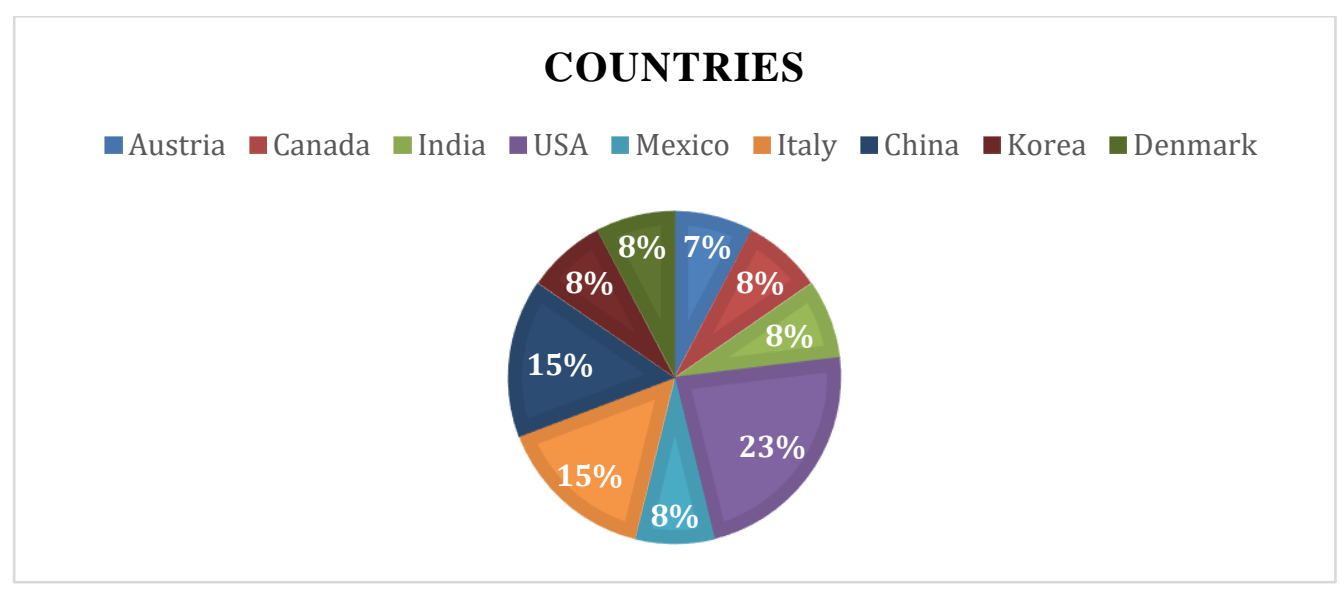

\section{Type of Data Analysis}

Figure 4 shows the type of analysis used to process and interpret information obtained from respondents. It can be seen that the SPSS device was the highest used in previous studies compared to other types of analysis.

Figure 4: Types of Data Analysis

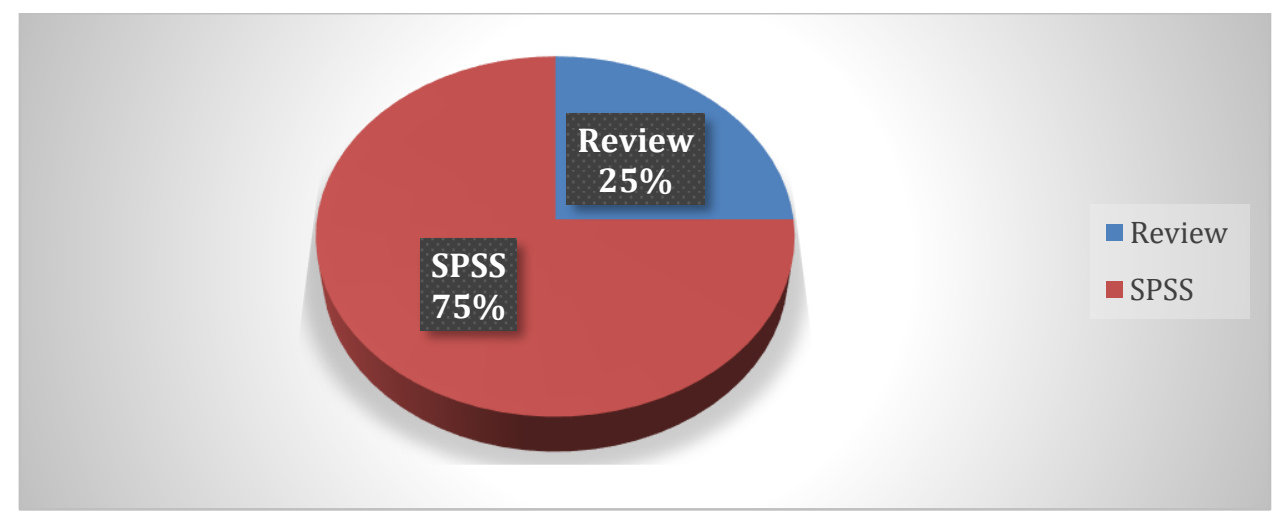




\section{Limitation and Direction for Future Work}

The focus of this study is on alcohol intake and cirrhosis of the liver, so further studies should be considered in the context of alcohol intake. To identify the issue, this study focused on 13 articles on the topic of alcohol abuse and cirrhosis of the liver. Therefore, the findings of this study are limited. To add more generalization to this topic, more articles will need to be reviewed. For the purpose of this study, more databases should be used to enrich the findings regarding alcohol consumption issues. The findings of the previous study indicate that there are low publications on this topic. It can be seen that the journals have the focus set forth in their publications while other journals have less focus on alcohol and serious problems due to the harm of consuming alcohol. Therefore, future studies should focus on and enrich important findings on alcohol-related topics. The selection of this article is short and focuses on searches from 2016 to 2019. This is to see the latest trends in alcohol-related topics. However, it can be seen that there has been an increase in the distribution of alcohol-related research findings over the years. This is due to the current awareness and need for the importance of this topic in line with other issues that lead to poor society.

The topic is also based on the background and needs of a country, its geographical distribution, and its demographic profile. Developing countries and especially in Europe are the highest contributors to alcohol consumption leading to various alcohol-related problems among its population. Even in countries with less alcohol-related problems, the harm and dangers of alcohol use should not be taken lightly. This is because alcohol use can be detrimental to the government, public health, medical sociology, family institution and the individual involved. Therefore, studies on alcohol consumption should be taken seriously by developing countries to better understand and focus on all aspects of existing systems improvement efforts so that the right solution can be channeled.

Previous studies have focused on the use of quantitative approaches, in which none or the least qualitative approaches and mixed modes are used. Therefore, future studies are needed to develop a qualitative approach to understanding health issues such as excessive alcohol consumption and social problems caused by alcohol use. Previous studies have focused on alcohol consumption and cirrhosis of the liver, so it is recommended for future studies to study risk behaviors, social problems, and quality of life of alcoholic drinkers.

\section{Conclusion}

This study is aimed at identifying issues related to alcohol consumption and liver cirrhosis. Therefore, a systematic literature review is used to gather important information and to highlight areas of low priority. The articles in this study are refined according to the focus of the study. The results show that a total of 13 articles were obtained after a systematic search. The study shows a few published publications based on their deep focus and interest in this topic. The highest study was conducted in the United States and furthermore, this study used quantitative methods. This study is limited and has been discussed in the scope of limitations.

\section{Acknowledgement}

The publication of this paper was supported by MPOB-UKM Endowed Chair, Research Grant EP2019-054.

\section{References}

Adzrago, D., Doku, D.T. \& Adu Gyamfi, A. B. (2018). Rehabilitation Processes involved in Rehabilitating Individuals with Alcohol and Drug Addictions at Rehabilitation Centres in Ghana. Journal of Addiction Research \& Therapy, 09(04).

Askgaard, G., Tolstrup, J.S., Kjær, M.S. \& Leon, D.A. (2019). Number of hospital contacts with 
alcohol problems predicts later risk of alcoholic liver cirrhosis. Scandinavian Journal of Public Health, 47(4), 417-419.

Campollo, O. (2019). Alcohol and the Liver: The Return of the Prodigal Son 18(1): 6-10.

Chick, J. 2011. The WHO Global Strategy to Reduce the Harmful Use of Alcohol. Alcohol and Alcoholism, 46(3), 223-223.

Demoury, C., Karakiewicz, P. \& Parent, M.-E. (2016). Association between lifetime alcohol consumption and prostate cancer risk: A case-control study in Montreal, Canada. Cancer Epidemiology, 45, 11-17.

Fernandez, A., Shedden, K., Winder, G.S., Mellinger, J.L., Fontana, R.J., Volk, M.L., Blow, F.C. \& Lok, A.S.F. (2019). Gender Disparities in Alcohol Use Disorder Treatment Among Privately Insured Patients with Alcohol-Associated Cirrhosis, 43(2), 334-341.

Fogarty, J.J. (2009). A review of alcohol consumption and alcohol control policies. Worldwide Hospitality and Tourism Themes, 1(2),110-132.

Gupta, A., Long, K. \& Bai, H.J. 2019. Role of Cirrhosis a review article. Social Science and Humanities Journal, 892-896.

Lackner, C. \& Tiniakos, D. (2019). Fibrosis and alcohol-related liver disease. Journal of Hepatology, 70(2), 294-304.

Li, Z., Bai, Y., Guo, X., Zheng, L., Sun, Y. \& Roselle, A.M. (2016). Alcohol consumption and cardiovascular diseases in rural China. International Journal of Cardiology, 215(August 2013): 257-262.

Lucey, M.R. (2019). C ir rhos is Cirrhosis Alcohol Liver disease Comorbidity. Clinics in Liver Disease, 23(1), 115-126.

Magistri, P., Marzi, L., Guerzoni, S. et al. (2019). Impact of a Multidisciplinary Team on Alcohol Recidivism and Survival After Liver Transplant for Alcoholic Disease. Transplantation Proceedings, 51(1), 187-189.

Mehrabi, M., Hajebi, A., Mohebbi, E., Reza, M. et al. (2019). Prevalence and Correlates of Lifetime Alcohol Use among Adult Urban Populations in Iran: A Knowledge, Attitude, and Practice Study Prevalence and Correlates of Lifetime Alcohol Use among Adult Urban. Journal of Psychoactive Drugs, 1-8.

Mellinger, J.L., Scott Winder, G., DeJonckheere, M., Fontana, R.J., Volk, M.L., Lok, A.S.F. \& Blow, F.C. (2018). Misconceptions, preferences and barriers to alcohol use disorder treatment in alcohol-related cirrhosis. Journal of Substance Abuse Treatment, 91, 20-27.

MOH Malaysia. (2013). Garis Panduan Saringan dan Intervensi Pencegahan dan Pengurangan Kemudaratan Alkohol.

Mutalip, M.H.B.A., Kamarudin, R.B., Manickam, M., Abd Hamid, H.A.B. \& Saari, R.B. (2014). Alcohol consumption and risky drinking patterns in Malaysia: Findings from NHMS 2011. Alcohol and Alcoholism, 49(5), 593-599.

Noor, L.M. et al. (2018). Alkohol: Definisi , Pengharaman , Metabolisme Dan Kegunaannya [ Alcohol: Definition, Prohibition, Metabolism and Its Usage ]. The Malaysian Journal of Islamic Sciences 23, 98-114.

Page, M.J., Mckenzie, J.E., Bossuyt, P.M. et al. (2021). The PRISMA 2020 statement: an updated guideline for reporting systematic reviews Systematic reviews and Meta-Analyses.

Song, D.S., Chang, U.I., Choi, S., Jung, Y.D., Han, K., Ko, S.-H., Ahn, Y.-B. \& Yang, J.M. 2016. Heavy Alcohol Consumption with Alcoholic Liver Disease Accelerates Sarcopenia in Elderly Korean Males: The Korean National Health and Nutrition Examination Survey 2008-2010. Plos One, 11(9), e0163222.

Stroffolini, T., Sagnelli, E., Sagnelli, C. (2018). Characteristics and Changes over Time of AlcoholRelated Chronic Liver Diseases in Italy. Canadian journal of gastroenterology \& hepatology, 9151820.

Xie, F., Feng, S. \& Mao, Y. (2019). Alcohol consumption as a cause of cancer: urging for more mechanism study. 